\title{
AOR
}

Selected Papers of \#AolR2018:

The $19^{\text {th }}$ Annual Conference of the

Association of Internet Researchers

Montréal, Canada / 10-13 October 2018

\section{MEDIATED DEATH AND DIGITAL MARTYRDOM: ETHICAL CONSIDERATIONS FOR VISUAL SOCIAL MEDIA RESEARCHERS}

Kelly Lewis

Digital Media Research Centre, Queensland University of Technology

\section{Introduction}

The digital mediation of visual content depicting death and martyrdom as a trope of resistance and contestation is increasingly employed within social media platforms by activist cultures and popular social movements. While the trope of death and martyrdom as a form of political expression and resistance is not a new phenomenon, what is different is how it is being performed through digital technologies and the affective, ritualised entanglements this engenders. Importantly for researchers, the mediation of death imagery that becomes witnessed as a public event - via digital technologies that enable the capture, dissemination and consumption of visual content - raises ethical considerations and implications for the design, collection, presentation and publishing of academic work.

The aim of this paper is to raise questions and provocations regarding the ethical challenges faced by researchers engaged in digital and visual social media research with respect to the mediation of death and posthumous imagery online. The questions presented in this paper have emerged out of a systematic study of death and martyrdom online, with a particular focus on case studies drawn from the Middle East and the United States.

\section{Researching Digital Martyrdom in Visual Social Media}

The emergence of digitally mediated martyrdom - a term I employ to refer to the contemporary visual social media phenomenon practiced within transnational activist cultures - can, arguably, be said to have materialised with the public Suggested Citation (APA): Lewis, K. (2018, October 10-13). Mediated Death and Digital Martyrdom: Ethical Considerations for Visual Social Media Researchers. Paper presented at AolR 2018: The 19 Annual Conference of the Association of Internet Researchers. Montréal, Canada: AolR. Retrieved from http://spir.aoir.org. 
witnessing of the death of Neda Agha-Soltan on June 20, 2009. Neda attended a street protest in Tehran against the disputed election of President Mahmoud Ahmadinejad when she was fatally shot by a government sniper. Onlookers recorded her final moments on their mobile phones and broadcast it on the internet for the world to witness. Through mobile phones, YouTube, Facebook, MySpace, Twitter, blogs and global mainstream media, the video footage of her death went viral with some claiming her death as one of the most widely witnessed in history (Mahr, 2009). Neda's image was mediated and remediated across digital and social media technologies and she became symbolically appropriated by the people as the martyr of the Iranian Green Movement.

My research explores the evolution of this phenomenon through a systematic analysis of visual content motivated in response to the brutal death of Khaled Said by Egyptian police in 2010, and the appropriation of his image in the 2011 Egyptian Revolution. It establishes digitally mediated martyrdom as a reoccurring theme that both persists within Middle Eastern-based conflicts, and which has emerged within transnational activist cultures and popular social movements. Displays of digitally mediated martyrdom manifest in occurrence with the unjust death of Trayvon Martin in 2012 and his posthumous symbolic appropriation as the face of the Black Lives Matter Movement in the United States. Moreover, the phenomenon of digitally mediated martyrdom is evident in popular uprisings that took place to protest the unjust death of Razan al-Najjar, a Gaza medic, who was shot by Israeli soldiers on 1 June 2018 while attending to injured victims during the demonstrations dubbed \#TheGreatReturnMarch. In her death, Razan al-Najjar has become an icon and appropriated as a martyr of Palestinian resistance. I argue a new form of martyrdom has emerged post the 2010-11 Egyptian uprisings: one that is digitally mediated by individuals through the affordances of visual social media and digital technologies; has given rise to new performative rituals of witnessing and commemoration; offers new possibilities for popular political participation and expression; and challenges the dominant ways of doing politics online.

\section{Findings and Implications}

At the core of this research the central questions emerged: What ethical obligations do researchers owe to victims of injustice and to their posthumous representation in our research? What ethical considerations do researchers owe to the posthumous rights of the deceased individual? What is the moral and ethical duty to the surviving family and the research audience? Should academic findings that address potentially distressing visual content discuss the impact of such visuals without explicitly showing them? As a visual-digital centric field of research does it make sense not to 'show' death and posthumous visuals that have already gained widespread publicity through their mass dissemination via digital and social media technologies? How should research in this field approach the legal and copyright complexities that arise when dealing with the ever-expanding array of visual social media content and platform affordances?

Further problematic questions arise for researchers who decide not to show visual 
content that depicts victims of specific acts of injustice, in particular those that serve as testimony to acts of violence and brutality. For example, in the case study analysis of Khaled Said the research finds his family employed digital and visual social media technologies with the explicit intent to give testimony to the act of injustice committed against Khaled. This raises an important moral and ethical question for me: if I as a researcher, investigating visual activist cultures and digital practices, do not honour this context by showing the visuals within the presentation and publication of my work, am I complicit in suppressing the act of injustice that Khaled's family were trying to give visibility to?

A rich body of literature addresses digital witnessing and the visual representation of death within environments of resistance and contestation (Chouliaraki, 2015; Mirzoeff, 2017). Yet scholarly thinking about the new ethical implications and moral dilemmas that arise through the memetic circulation of death and posthumous imagery - in its diffusion, collectivism and reappropriation within visual social media platforms - are undertheorised and analysed, and merit specific ethical considerations. This ethical imperative is of particular importance for visual social media research that extends beyond a Western context and considers the cross-cultural, transnational dimensions of memetic protest.

Visual social media play a role in how we experience death and make meaning from death events. This signifies new possibilities for performative rituals of witnessing and commemoration, and a new terrain for researchers to study emergent digital death practices within visual social media platforms. Importantly, within an activist context, it presents researchers with the opportunity to consider the ways activists and citizens strategically and symbolically employ narratives of death and martyrdom as a means to give visibility to injustice and mobilise global publics. The imperative here is to ensure the research approach is ethically informed and that regulatory and disciplinary structures evolve to accommodate the increasing complexities and ethical implications of doing research online.

\section{References}

Mahr, K. (2009) 'Neda Agha-Soltan'. Time Magazine (online article 8 December). Retrieved from http://content.time.com/time/specials/packages/article/0,28804,1945379 19447011 $\underline{944705,00 . \mathrm{html}}$

Chouliaraki, L (2015) Mediatized Death in Post-Arab Spring Conflicts. In Eskjær, M. F., Hjarvard, S., and Mortensen, M. (eds.) The Dynamics of Mediatized Conflicts. New York: Peter Lang. Global Crises and the Media, Vol. 3. 
Mirzoeff, N. (2017) The Appearance of Black Lives Matter. Society. Name Publications. 